\title{
Towards deeper collaboration: stories of Indigenous interests, aspirations, partnerships and leadership in aquatic research and management
}

\author{
David A. Crook $\cdot$ Michael M. Douglas $\cdot$ Alison J. King $\cdot$ Stephan Schnierer
}

Published online: 5 October 2016

(C) Springer International Publishing Switzerland 2016

We have been a part of the lands so long that we, through that nutrient cycle, our flesh is put into the ground and becomes part of the soil and nourishes the grass, the trees, the animals that we eat. We become part of them. We become related to them. When we use these things or eat these things in our ceremony we give thanks because it is our relations that are keeping us alive. - Mi'kmaq elder Kerry Prosper on the concept of "Netukulimk" (McMillan and Prosper 2016).

Recognition of the role of Indigenous peoples in the management and research of natural systems and resources continues to grow globally (Jentoft et al. 2003; Ens et al. 2015). This has largely come about due to greater acknowledgement of Indigenous peoples' rights, interests and, increasingly, a wider appreciation of the value of Indigenous Ecological

D. A. Crook $(\varangle) \cdot$ M. M. Douglas · A. J. King Research Institute for the Environment and Livelihoods, School of Environment, Charles Darwin University, Darwin, NT, Australia

e-mail: david.crook@cdu.edu.au

M. M. Douglas

School of Earth and Environment, The University of

Western Australia, Crawley, WA, Australia

\section{S. Schnierer}

School of Environment, Science and Engineering, Southern Cross University, Lismore, NSW, Australia
Knowledge (IEK) (Hill et al. 2012; Barber 2015). IEK can be valuable for natural resource management by providing fine-grained, detailed information on local ecosystem patterns and processes (Fabricius et al. 2006; Wohling 2009). This is especially important in areas with extant systems of customary resource management and where scientific knowledge (SK) is low or non-existent (Fabricius et al. 2006). The diversity in knowledge systems provided by combining SK and IEK also provides complementary sources of information that can be highly beneficial for researchers, natural resource managers and policy makers (Healy 1993; Berkes 2000; Christie 2006; Nakata 2007; Noble et al. 2016). The value of IEK in this context is evident in the growing number of studies applying it to a range of natural resource management issues (e.g., Silvano and Begossi 2002; Silvano et al. 2008; Stephenson and Moller 2009; Bohensky and Maru 2011; Berkes 2012; Jackson et al. 2014). Importantly, inclusion of Indigenous people and IEK in natural resource management and research also has a wide range of cultural, social, political and economic co-benefits for Indigenous people and communities (Campbell et al. 2011; Barber 2015).

Aquatic ecosystems are among the most vulnerable ecosystems throughout the world, due to the rapid increase in the demand for aquatic resources (especially fisheries) and hydrological changes resulting from the consumption of fresh water to support a 
growing human population, as well as the interacting effects of climate change (see Dulvy et al. 2003; Roessig et al. 2004; Dudgeon et al. 2006). Sustainably managing aquatic resources is therefore a global challenge, but is even more significant in regions where scientific knowledge is sparse and where anthropogenic use of water and development is occurring rapidly (Dulvy et al. 2003; Vörösmarty et al. 2010). For example, the lack of sufficient SK to underpin fisheries management has contributed to some well-documented fishery collapses (Ludwig et al. 1993), and the lack of time and resources to secure sufficient SK for all fisheries has led to calls to consider fisheries management options that make use of alternative knowledge sources (Johannes 1998). Indigenous people often have knowledge of direct relevance to fisheries management and there are welldocumented examples where customary management of fisheries has been used in their sustainable management (e.g., Johannes, 1981).

As the rights and interests of Indigenous people are formally recognised under Government legislation in different regions of the world, the roles of Indigenous people as researchers and managers of aquatic resources have assumed increased significance. For example, legal recognition of Indigenous rights over the past few decades has provided Maori people with control of almost half of the New Zealand seafood industry, while First Nations people now control nearly one-third of Canada's commercial fishing fleet (Durette 2007). In Australia, Aboriginal people have recently been granted Native Title rights over large parts of the northern Australian coastline: for example, the 2008 "Blue Mud Bay" High Court decision under the Aboriginal Land Rights (Northern Territory) Act 1976) that granted traditional owners exclusive native title rights to the intertidal zone.

Greater engagement and collaboration between Indigenous and non-Indigenous people has the potential to provide wide benefits for research and management of aquatic natural resources. However, realising this potential will require a shift in thinking by many natural resource managers and researchers, as pursuing collaboration with Indigenous people will, in many cases, be a new and possibly daunting prospect (and vice versa). In Australia, the strong connection of Indigenous people to aquatic ecosystems and, therefore their knowledge of those systems, is not well understood or appreciated by mainstream aquatic ecologists and managers (Humphries 2007; Jackson et al. 2014), and biocultural knowledge is poorly documented for freshwater habitats relative to other ecosystem science and management priorities (Ens et al. 2015).

\section{A meeting to foster relationships and understanding}

A joint meeting of the Australian Society for Fish Biology (ASFB) and Australian Society for Limnology (ASL) was held in Darwin in Australia's famous “Top End" from June 30th to July 4th 2014. Under the theme of "Indigenous participation and partnerships in aquatic research and management", the conference program included a series of keynote presentations relating to Indigenous interests, aspirations, partnerships and leadership in aquatic research and management. By sharing experiences about these issues with examples from Australia, New Zealand and Canada, the aim of the plenary sessions was to encourage greater recognition and understanding of IEK and the connections of Indigenous people to aquatic ecosystems, foster relationship-building between society members and Indigenous people with interests in the aquatic environment, and inspire increased collaboration and greater inclusion of Indigenous people in the future activities of the two societies.

In addition to the plenary presentations, the conference program included an open discussion where a panel of Indigenous and non-Indigenous stakeholders, researchers and managers led a wide-ranging discussion of topics related to the plenary theme. There were also special sessions devoted to IEK and partnerships with Indigenous people within the general conference schedule. A cross-cultural training course targeted at postgraduate students was conducted prior to the conference, with the aim of fostering understanding of Indigenous knowledge, cultural diversity, beliefs and values among the next generation of aquatic ecologists. This session was run by an Indigenous academic from Charles Darwin University, followed by an 'on country' field trip run by a local Indigenous family business, where participants were provided hands-on experiences of traditional foods, hunting, basket weaving, medicines and customs.

This special issue of Reviews in Fish Biology and Fisheries is a collection of eight papers covering many 
of the issues raised during the plenary sessions and panel discussion at the ASFB/ASL conference. Five of the papers Gould (2016), Ligtermoet (2016), McMillan and Prosper (2016), Rose et al. (2016), Schnierer and Egan (2016) focus on Indigenous livelihoods around fish or fisheries resources. All consider the challenges in undertaking traditional harvesting or fisheries management practices under contemporary management regimes, particularly those that give primacy to non-Indigenous fishers and fisheries management methods (Gould, McMillan and Prosper, Schnierer and Egan). McMillan and Prosper (2016) describe the long and continuing struggle of the Mi'kmaq in Atlantic Canada for fisheries management that appropriately recognises Indigenous rights and ecological knowledge, and advocate for a more inclusive approach to stewardship of aquatic resources. They conclude with a poignant description of the Mi'kmaq concept of "Netukulimk": an allencompassing framework describing the interconnections between people and natural resources that points to a way of sustainably sharing natural resources across generations.

Rose et al. (2016) describe a long history of traditional fisheries management involving the harvest and culture of eels in south-eastern Australia by Gunditjmara, which was disrupted by colonisation and is now being reinvigorated through a program of restoration of freshwater lake habitat. Schnierer and Egan (2016) provide the first detailed synthesis of Indigenous harvest of fisheries resources in New South Wales and discuss the overlap with the commercial and recreational fishing sectors and the need for increased recognition of the Indigenous harvest in fisheries management. In a study conducted in the West Arnhem Land region of northern Australia, Gould (2016) describes the history of involvement of Indigenous people in the trepang (sea cucumber) fishery and the opportunities and challenges associated with trepang aquaculture as a culturally appropriate livelihood for community members in the future. All of these papers describe the significant challenges for Indigenous people attempting to reinvigorate culturally appropriate fisheries activities under colonial systems of fisheries governance which have given legal rights to nonIndigenous fishers. Ligtermoet (2016) also explores the challenges of sustaining customary harvest of resources amid contemporary systems of governance.
She identifies the circumstances under which livelihoods currently derived from non-customary use of floodplains-including tourism, cattle grazing and biodiversity conservation-support or constrain the maintenance of livelihoods based on the customary harvest of floodplain resources by Bininj in the East Alligator region of northern Australia.

Many of the cases where IEK has been applied to natural resource management have come from close collaboration between Indigenous people and nonIndigenous researchers and/or resource managers. Three papers in this issue focus on research collaborations relating to fish habitat and fisheries. Dobbs et al. (2016) describe a collaborative research partnership to improve management and monitoring of wetland ecosystems in the West Kimberley in northern Australia. Both IEK and SK were used to help Indigenous Nyul Nyul rangers respond to threats to the health of wetlands and to monitor their condition. Prescott et al. (2016) describe a collaborative research project with traditional Indonesian fishers of trepang around Scott Reef in north-western Australia. This project worked with fishers who provided catch data that facilitated more accurate monitoring than data collected independently of the fishers. Finally, Saunders and Xeureb (2016) describe a training program that provided accredited skills to Indigenous rangers in fish data collection with the potential to support fisheries monitoring and assessment. This program has since led to the employment of some of the participants in fisheries research projects, thus providing a cost-effective and inclusive approach to data collection and monitoring in remote areas.

In addition to highlighting the benefits of partnership and collaboration, many of the papers in this issue identify consistent challenges, including: the time required for researchers and Indigenous people to develop trusting relationships; recognition and sharing of intellectual property; the importance of the continuity of relationships; the need for mechanisms to ensure that researchers are aware of consultation requirements and cultural appropriateness; the need for provision of specific funding and input into priority setting/decision making; and the need to recognise, plan for and adequately resource collaborative approaches. Similar lists of challenges have been raised previously in relation to aquatic resources (Jackson and Douglas 2015; Liddy and Allsop 2014) and are reflected in general principles for more 
effective collaboration between Indigenous and nonIndigenous people (Ens et al. 2012, 2015). It is also worth noting that these papers consistently raise the necessity for a shift in the nature of engagement toward a deeper level of collaboration. Hill et al. (2012) proposed a typology of Indigenous engagement that ranges from "Agency governance" to "Indigenous co-governance", and noted that shifting toward Indigenous co-governance requires changes in power sharing, the level of participation and the intercultural purpose of the engagement.

\section{Building on the momentum}

The plenary theme and subsequent formal and informal discussions during the conference created significant momentum for change within ASFB and ASL. The topic was discussed in depth during the 2014 Annual General Meetings of the two societies, and both resolved to increase Indigenous engagement in their activities and within their memberships. As organisers of the plenary sessions (and members of the societies), we are pleased to acknowledge that many of the items discussed have since been actioned by ASFB and ASL. This includes the addition of an Indigenous representative position on the ASL National Executive Committee, inclusion of specific acknowledgment of Indigenous people in the ASFB constitution, establishment of Indigenous working groups within both societies to foster engagement with Indigenous people, travel scholarships for Indigenous people to attend and present at ASL conferences, standing conference sessions on IEK and Indigenous engagement, methods to more effectively share information among researchers about collaborative research involving Indigenous people, and engagement of local Indigenous people to encourage their participation in annual conferences.

It is clear from these decisive actions that a strong will exists within ASFB and ASL to build upon the momentum achieved during the Darwin conference. As the papers in this special issue and other outputs resulting from the plenary sessions (e.g., Noble et al. 2016) collectively demonstrate, a conscious and sustained effort is required to overcome the factors that have hindered engagement of Indigenous people in aquatic research and management in the past. It is our hope that this special issue, the relationships initiated and built upon during the conference, and the actions instituted following the conference, will go some way towards fostering this positive change.

Acknowledgments The authors acknowledge and pay respects to the Larrakia traditional owners of the Darwin region upon which the 2014 ASFB/ASL joint conference was held. We acknowledge all of the plenary speakers and the authors of the papers for their valuable contributions to the conference and special issue. We are especially grateful to the editorial team at Reviews in Fish Biology and Fisheries for their patience and encouragement with this special issue. We thank the conference sponsors (in particular Fisheries Research Development Corporation and Charles Darwin University) for their financial support of the conference, and the conference organising committee and their employers for their important contributions that ensured the success of the plenary sessions. The support and interest of the executive committees of the Australian Society for Fish Biology and the Australian Society for Limnology are greatly appreciated and we thank the attendees of the conference for their engagement and positive contributions.

\section{References}

Barber M (2015) Beyond the local: assessing the external social outcomes of Indigenous environmental management. Key concepts and a case study of the Kowanyama Aboriginal Land and Natural Resources Management Office. CSIRO, Brisbane

Berkes F (2000) Rediscovery of traditional ecological knowledge as adaptive management. Ecol Appl 10:1251-1262

Berkes F (2012) Sacred ecology: traditional ecological knowledge and resource management, 3rd edn. Routledge, New York

Bohensky EL, Maru Y (2011) Indigenous knowledge, science, and resilience: What have we learned from a decade of international literature on "integration"? Ecol Soc 16:6

Campbell D, Burgess CP, Garnett ST, Wakerman J (2011) Potential primary health care savings for chronic disease care associated with Australian Aboriginal involvement in land management. Health Policy 99:83-89

Christie M (2006) Transdisciplinary research and Aboriginal knowledge. Aust J Indig Ed 35:78-98

Dudgeon D, Arthington AH, Gessner MO, Kawabata ZI, Knowler DJ, Lévêque C, Naiman RJ, Prieur-Richard AH, Soto D, Stiassny ML, Sullivan CA (2006) Freshwater biodiversity: importance, threats, status and conservation challenges. Biol Rev 81:163-182

Dulvy NK, Sadovy Y, Reynolds JD (2003) Extinction vulnerability in marine populations. Fish Fish 4:25-64

Durette M (2007) Indigenous property rights in commercial fisheries: Canada, New Zealand and Australia Compared. CAEPR Working Paper No. 37/2007. Centre for Aboriginal Economic Policy Research, ANU, Canberra

Ens EJ, Finlayson CM, Preuss K, Jackson S, Holcombe S (2012) Australian approaches for managing 'country' using Indigenous and non-Indigenous knowledge. Ecol Manag Restor 13:100-107 
Ens EJ, Pert P, Clarke PA, Budden M, Clubb L, Doran B, Douras C, Gaikwad J, Gott B, Leonard S, Locke J, Packer J, Turpin G, Wason S (2015) Indigenous biocultural knowledge in ecosystem science and management: review and insight from Australia. Biol Conserv 181:133-149

Fabricius C, Scholes R, Cundill G (2006) Mobilizing knowledge for integrated ecosystem assessments. In: Reid WV, Berkes F, Wilbanks TJ, Capistrano D (eds) Bridging scales and knowledge systems: concepts and applications in ecosystem assessment. Island Press, Washington, pp 165-182

Gould J (2016) Caught in the tides: the (re)development of a trepang (sea cucumber, Holothuria scabra) industry at Warruwi, Northern Territory. Rev Fish Biol Fish. doi:10. 1007/s11160-015-9400-3

Healy C (1993) The significance and application of TEK. In: Williams NM, Baines G (eds) Traditional ecological knowledge: wisdom for sustainable development. Centre for Resource and Environmental Studies, Australian National University, Canberra, pp 147-150

Hill R, Grant C, George M, Robinson CJ, Jackson S, Abel N (2012) A typology of Indigenous engagement in Australian environmental management: implications for knowledge integration and social-ecological system sustainability. Ecol Soc 17:23

Humphries P (2007) Historical Indigenous use of aquatic resources in Australia's Murray-Darling Basin, and its implications for river management. Ecol Manag Restor 8:106-113

Jackson SE, Douglas M (2015) Indigenous engagement in tropical river research in Australia: the TRaCK program. Int Indig Policy J 6(2)

Jentoft S, Minde H, Nilsen R (eds) (2003) Indigenous peoples: resource management and global rights. Eburon, Delft

Johannes RE (1981) Words of the lagoon: fishing and marine lore in the Palau district of Micronesia. University of California Press, Berkeley

Johannes RE (1998) The case for data-less marine resource management: examples from tropical nearshore finfisheries. Trends Ecol Evol 13:243-246

Jackson SA, Douglas MM, Pusey BJ, Kennard MJ, Huddleston J, Harney B, Liddy, L, Liddy M., Liddy R, Sullivan L, Huddleston B, Banderson M. McMah A, Allsop, Q (2014) 'We like to listen to stories about fish': improving aquatic system understanding and management with indigenous knowledge. Ecol Soc 19:Art. 43

Ligtermoet E (2016) Maintaining customary harvesting of freshwater resources: sustainable Indigenous livelihoods in the floodplains of northern Australia. Rev Fish Biol Fish. doi:10.1007/s11160-016-9429-y

Ludwig D, Hilborn R, Walters C (1993) Uncertainty, resource exploitation, and conservation: lessons from history. Science 260:17-36
McMillan LJ, Prosper K (2016) Remobilizing Netukulimk: indigenous cultural and spiritual connections with resource stewardship and fisheries management in Atlantic Canada. Rev Fish Biol Fish. doi:10.1007/s11160-016-9433-2

Nakata MN (2007) Disciplining the savages, savaging the disciplines. Indigenous Studies Press, Canberra

Noble M, Duncan P, Perry D, Prosper K, Rose D, Schnierer S, Tipa G, Williams E, Woods R, Pittock J (2016) Culturally significant fisheries: keystones for management of freshwater social-ecological systems. Ecol Soc 21:22

Prescott J, Riwu J, Stacey N, Prasetyo A (2016) An unlikely partnership: fishers' participation in a small-scale fishery data collection program in the Timor Sea. Rev Fish Biol Fish. doi:10.1007/s11160-015-9417-7

Dobbs RJ, Davies CL, Walker ML, Pettit NE, Pusey BJ, Close, PG, Akune Y, Walsham N, Smith B, Wiggan A, Cox P, Ward DP, Tingle F, Kennett R, Jackson MV, Davies PM (2016) Collaborative research partnerships inform monitoring and management of aquatic ecosystems by Indigenous rangers. Rev Fish Biol Fish. doi:10.1007/s11160-0159401-2

Roessig JM, Woodley CM, Cech JJ Jr, Hansen LJ (2004) Effects of global climate change on marine and estuarine fishes and fisheries. Rev Fish Biol Fish 14:251-275

Rose D, Bell D, Crook DA (2016) Restoring habitat and cultural practice in Australia's oldest and largest traditional aquaculture system. Rev Fish Biol Fish 26:589-600

Saunders T, Xuereb S (2016) Optimising the monitoring of tropical aquatic resources through the development of indigenous science capability. Rev Fish Biol Fish. doi:10. 1007/s11160-016-9451-0

Schnierer S, Egan H (2016) Composition of the Aboriginal harvest of fisheries resources in coastal New South Wales, Australia. Rev Fish Biol Fish. doi:10.1007/s11160-0169452-z

Silvano RAM, Begossi A (2002) Ethnoichthyology and fish conservation in the Piracicaba River (Brazil). J Ethnobiol 22:285-306

Silvano RAM, Silva AL, Ceroni M, Begossi A (2008) Contributions of ethnobiology to the conservation of tropical rivers and streams. Aquat Conserv 18:241-260

Stephenson J, Moller H (2009) Cross-cultural environmental research and management: challenges and progress. J R Soc NZ 39:139-149

Vörösmarty CJ, McIntyre PB, Gessner MO, Dudgeon D, Prusevich A, Green P, Glidden S, Bunn SE, Sullivan CA, Liermann CR, Davies PM (2010) Global threats to human water security and river biodiversity. Nature 467:555-561

Wohling M (2009) The problem of scale in Indigenous knowledge: a perspective from Northern Australia. Ecol Soc 14:Art 1 